\title{
Hubungan antara Parent Attachment dengan Regulasi Emosi pada Remaja
}

\author{
FAADHILA SYAFI AMIRA \& ENDAH MASTUTI* \\ Fakultas Psikologi Universitas Airlangga
}

\begin{abstract}
ABSTRAK
Penelitian ini bertujuan untuk mengetahui hubungan antara parent attachment dengan regulasi emosi pada remaja. Definisi regulasi emosi mengacu pada teori Gross dan parent attachment mengacu pada teori Armsden \& Greenberg. Metode yang digunakan dalam penelitian ini adalah kuantitatif. Skala yang digunakan ialah Inventory Parent and Peer Attachment (IPPA) dan Emotion Regulation Questionnaire (ERQ). Berdasarkan hasil penelitian uji korelasi diperoleh variabel parent attachment dengan regulasi emosi cognitive reappraisal menunjukkan korelasi 0,118 dengan $\mathrm{p}=0,006(\mathrm{p}<0,01)$ menyatakan bahwa semakin tinggi parent attachment, maka semakin tinggi cognitive reappraisal. Sementara, uji korelasi variabel parent attachment dengan regulasi emosi expressive suppression menunjukkan korelasi -0,101 dengan $\mathrm{p}=0,015(\mathrm{p}<0,05)$ menyatakan bahwa semakin tinggi parent attachment maka semakin rendah expressive suppression.
\end{abstract}

Kata kunci: parent attachment, regulasi emosi, remaja

\begin{abstract}
This study aims to find out the correlation between parent-attachment with emotion regulation in adolescent. Definition of emotion regulation refers to the theory stated by Gross and parent attachment refers to the theory stated by Armsden and Greenberg. This study uses quantitative approach. Scales uses in this study are Inventory Parent and Peer Attachment (IPPA) and Emotion Regulation Questionnaire (ERQ). The result of variable correlation test between parent attachment and cognitive reappraisal shows correlation 0,118 with $p=0,006(p<0,01)$, indicated that the higher parental attachment, the higher the cognitive reappraisal. While the result of variable correlation test between parent attachment with expressive suppression shows correlation 0,101 with $p=0,015$ with $p=0,015(p<0,05)$, indicated that the higher parental attachment, the lower the expressive suppression.
\end{abstract}

Keywords: adolescent, emotion regulation, parent attachment

Buletin Penelitian Psikologi dan Kesehatan Mental (BRPKM), 2021, Vol. 1(1), 837-843

*Alamat korespondensi: Fakultas Psikologi Universitas Airlangga, Kampus B Universitas Airlangga Jalan Airlangga 4-6 Surabaya 60286. Surel: endah.mastuti@psikologi.unair.ac.id

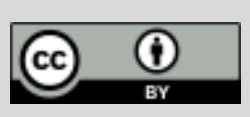

Naskah ini merupakan naskah dengan akses terbuka dibawah ketentuan the Creative Common Attribution License (CC-BY-4.0) (http://creativecommons.org/licenses/by/4.0), sehingga penggunaan, distribusi, reproduksi dalam media apapun atas artikel ini tidak dibatasi, selama sumber aslinya disitir dengan baik. 


\section{PEN D A H U L UAN}

Remaja disebut juga dengan masa storm and stress, karena remaja akan mengalami perubahan suasana hati dan konflik. Pikiran, perasaan dan tindakan remaja akan bimbang antara sikap sombong dan rendah hati, niat baik dan niat buruk, serta kebahagiaan dan kesedihan (Santrock, 2014). Ketidakstabilan secara emosional rentan untuk terjadi saat masa remaja. Semakin besar tekanan yang dialami remaja, dibutuhkannya figur lekat saat remaja melalui suatu masalah. Seseorang pada masa ini akan menghadapi tantangan tentang bagaimana kehidupan mereka kelak, arah yang akan mereka tempuh, dan tantangan menemukan siapa dirinya (Santrock, 2012). Menurut Rosenblum \& Lewis suasana hati dan emosi negatif seringkali berubah-ubah saat masa remaja. Pada masa remaja emosi naik dan turun cenderung lebih sering dimunculkan (Santrock, 2014). Sebanyak 6,1 persen remaja di Denpasar dengan rentang usia 15-24 tahun remaja usia 15-24 tahun di Bali mengalami gangguan mental emosional karena kesulitan remaja dalam mengekspresikan emosi dan pendapatnya (NusaBali.com, 2019). Berdasarkan penelitian Alfian (2014) sebanyak 59,1 \% mahasiswa suku Bima dengan rentang usia 1822 tahun memiliki emosi negatif yang tinggi jika dibandingkan dengan mahasiswa Suku Jawa dan Suku Banjar. Hal ini menunjukkan bahwa usia remaja akhir belum tentu mampu dalam mengelola emosinya.

Kebanyakan remaja tidak bisa secara efektif mengelola emosinya (Steinberg, 2014). Sebagai hasilnya, remaja rentan dengan depresi, amarah dan regulasi emosi yang buruk akan memicu masalah seperti kesulitan akademik, penyalahgunaan narkoba, kenakalan remaja, dan gangguan makan (Santrock, 2014). Kebiasaan remaja dalam menguasai berbagai emosi negatif dapat membuat remaja mampu mengontrol emosi dalam berbagai situasi. Emosi tersebut menurut Damon dan Eisenberg ialah usaha seseorang dalam mempertahankan, mengubah, atau menentukan hubungan antara individu dengan lingkungan supaya sesuai dengan keinginannya (Damon \& Eisenberg, 1998 dalam Nisfiannoor \& Kartika, 2004). Kemampuan individu mengelola emosi yang mereka miliki, seperti bagaimana mereka mengalami, kapan mereka merasakannya dan cara mengekspresikan emosi disebut dengan regulasi emosi (Gross, 1998). Dalam regulasi emosi terdapat dua strategi yaitu cognitive reappraisal dan expressive suppression. Cognitive reappraisal merupakan perubahan dari cara berpikir individu mengenai situasi yang berpotensi mengubah dampak emosionalnya. Sementara expressive suppression merupakan response modulation yang melibatkan emosi yang berlangsung menjadi terhambat atau perubahan respon yang melibatkan penghambatan pada perilaku emosi ekspresif (Gross \& John, 2003).

Menurut Calkins \& Hill faktor yang mempengaruhi regulasi emosi individu, ialah faktor intrinsik dan ekstrinsik yang terdiri dari beberapa faktor. Dalam faktor intrinsik, temperamen anak ialah karakteristik yang terlihat sejak lahir dan akan menetap pada individu, sistem saraf dan fisiologis termasuk faktor intrinsik karena berkaitan dan mendukung proses pengaturan regulasi emosi individu. Dalam faktor ekstrinsik, regulasi emosi dipengaruhi dari bentuk pengasuhan orang tua serta hubungan kelekatan antar individu (Gross, 2007). Menurut Santrock, remaja dengan kelekatan aman bersama orang tua, kecil kemungkinan untuk melakukan perilaku bermasalah (Efriani, 2019). Anak dengan kelekatan aman, melalui interaksi berkelanjutan dengan pengasuh yang luwes dan peka, mendorong berbagai emosi anak dan terbuka mengekspresikan emosi mereka, dalam hubungan kelekatan mampu belajar cara efektif dalam mengelola emosi negatif. Pada situasi dengan tekanan, mampu meringankan penderitaan mereka dan kembali bereksplorasi pada lingkungannya (Contreas, J. M. dkk, 2000 dalam Pawulan dkk., 2018).

Hubungan antara orang tua dan remaja dapat dilihat melalui kualitas hubungan yang terjalin antara orang tua dan remaja, seperti memberikan ruang dalam mengembangkan kehidupan sosial anak, komunikasi dua arah yang dilakukan orang tua dengan anak, dan orang tua mengontrol aktivitas remaja (Santrock, 2003). Kelekatan terhadap orang tua pada masa remaja dapat membantu kompetensi sosial 
dan kesejahteraan sosial pada remaja (Santrock, 2014). Armsden \& Greenberg (2009) mengungkapkan parent attachment merupakan hubungan anak dengan orang tuanya yang mampu menjadi sumber keamanan psikologis bagi anak. Berdasarkan yang sudah dijelaskan sebelumnya, parent attachment mempunyai dampak positif dalam perkembangan remaja. Peneliti tertarik untuk mengetahui apakah terdapat hubungan antara parent attachment dengan regulasi emosi pada remaja untuk meningkatkan kemampuan remaja dalam regulasi emosi dirinya.

\section{Desain Penelitian}

\section{E T O D E}

Tipe penelitian yang digunakan ialah penelitian kuantitatif dengan explanatory research guna mencari hubungan antara satu variabel dengan variabel yang lain. Teknik pengambilan data dalam penelitian ini menggunakan metode survei. Pengambilan data dilakukan dengan menyebarkan kuesioner secara online melalui web survey. Tujuan dari penelitian ini ialah melihat ada tidaknya hubungan antara parent attachment dengan regulasi emosi pada remaja, maka dari itu uji hipotesis menggunakan penelitian kuantitatif. Variabel independen dalam penelitan ini ialah parent attachment, sedangkan variabel dependen dalam penelitian ini ialah regulasi emosi.

\section{Partisipan}

Dalam penelitian ini menggunakan teknik non-probability sampling dengan metode purposive sampling. Penulis menetapkan rentang usia kriteria bagi partisipan yaitu berusia 12-21 tahun dan memiliki orang tua lengkap. Sebelum partisipan mengisi kuesioner, partisipan diberikan informed consent terlebih dahulu. Partisipan dalam penelitian ini berjumlah 462 partisipan, 75,8\% partisipan berjenis kelamin perempuan dan $24,2 \%$ partisipan berjenis kelamin laki-laki.

\section{Pengukuran}

Skala parent attachment penulis menggunakan IPPA (Inventory of Parent and Peer Attachment) oleh Armsden \& Greenberg pada tahun 1987. Pada penelitian ini, variabel parent attachment diukur dengan menggunakan skala adaptasi milik Dewi (2019) dengan skor reliabilitas sebesar 0,905. Skala ini terdiri dari 25 item mother attachment, 25 item father attachment dan 25 item peer attachment. Pada penelitian ini yang digunakan hanyalah 25 item mother attachment dan 25 item father attachment tanpa menggunakan item peer attachment dalam skala IPPA. Skala IPPA menggunakan skala likert dengan lima pilihan jawaban yaitu sangat tidak setuju (STS), tidak setuju (TS) Netral (N) setuju (S) dan sangat setuju (SS).

Skala regulasi emosi penulis menggunakan skala Emotion Regulation Questionnaire yang mengacu pada teori regulasi emosi Gross \& John (2003) diukur dengan menggunakan skala adaptasi milik Sepda (2018). Uji reliabilitas menghasilkan dimensi reappraisal sebesar 0.688 dan dimensi suppression sebesar 0,604. Skala ini terdiri dari 10 item dan termasuk skala Likert yang memiliki 7 pilihan jawaban, mulai 1 (sangat tidak setuju) hingga 7 (sangat setuju). Ketentuan pemberian skor skala terpisah antara kedua dimensi, reappraisal dan suppression. Karena keduanya memiliki konsekuensi yang berbeda

Uji asumsi yang dilakukan pada penelitian ini ialah uji normalitas dan uji linear untuk mengetahui data yang terkumpul parametrik atau non-parametrik sebelum melakukan uji korelasi. Variabel parent attachment memiliki nilai skewness dengan angka -0,164 menunjukkan variabel memiliki skor responden yang berada pada kategori nilai tinggi dan pada bagian kanan data dan nilai kurtosis dengan angka -0,329 menunjukkan memiliki nilai negatif dan cenderung datar. Serta variabel regulasi emosi dengan skewness pada variabel reappraisal menunjukkan angka -0,553, sehingga distribusi data 
cenderung sisi kanan dengan kategori tinggi dan pada variabel suppression menunjukkan angka -0,165, sehingga distribusi data cenderung sisi kanan dengan kategori tinggi. Nilai kurtosis variabel reappraisal menunjukkan angka 0,756 sehingga distribusi data cenderung runcing, sementara nilai kurtosis variabel suppression menunjukkan angka -0,425 sehingga distribusi data cenderung datar.

Penulis juga melakukan uji linearitas, nilai signifikansi linearitas parent attachment dengan cognitive reappraisal sebesar $\mathrm{p}=0,041$. Nilai berikut menunjukkan adanya hubunagn linear signifikan karena nilai signifikansi kurang dari 0,05. Sementara, nilai signifikansi parent attachment dengan expressive suppression sebesar $\mathrm{p}=0,058$ sehingga menunjukkan tidak adanya hubungan yang linear.

\section{Analisis Data}

Penulis melalukan beberapa uji asumsi yaitu uji normalitas dan uji linearitas. Proses pengolahan data menggunakan SPSS 22.0 for Mac. Analisis data dalam penelitian ini menggunakan uji korelasi untuk mengetahui apakah terdapat hubungan antar variabel.

\section{H A S I L P E N EL I T I A N}

Berdasarkan hasil analisis deskriptif terdapat total 462 partisipan. Skor rata-rata pada variabel parent attachment ialah 168,91 dengan standar deviasi sebesar 31,905. Sedangkan skor rata-rata variabel regulasi emosi pada pada reappraisal sebesar 31,92 dan suppression sebesar 18,46. Serta standar deviasi reappraisal sebesar 5,391 dan suppression sebesar 4,727. Variabel parent attachment memiliki nilai skewness dengan angka -0,164 menunjukkan variabel memiliki skor responden yang berada pada kategori nilai tinggi dan pada bagian kanan data dan nilai kurtosis dengan angka -0,329 menunjukkan memiliki nilai negatif dan cenderung datar. Serta variabel regulasi emosi dengan skewness pada variabel reappraisal menunjukkan angka -0,553, sehingga distribusi data cenderung sisi kanan dengan kategori tinggi dan pada variabel suppression menunjukkan angka -0,165, sehingga distribusi data cenderung sisi kanan dengan kategori tinggi. Nilai kurtosis variabel reappraisal menunjukkan angka 0,756 sehingga distribusi data cenderung runcing, sementara nilai kurtosis variabel suppression menunjukkan angka 0,425 sehingga distribusi data cenderung datar.

Berdasarkan hasil uji korelasi skor parent attachment dengan regulasi emosi cognitive reappraisal menunjukkan korelasi sebesar 0,118 dengan korelasi positif. Sementara, skor parent attachment dengan regulasi emosi expressive suppression menunjukkan korelasi sebesar -0,101 dengan korelasi negatif.

\section{I S K U S I}

Berisi penjelasan mengenai hasil penelitian (interpretasi data penelitian), dikaitkan dengan hasil penelitian-penelitian sebelumnya, dianalisis secara kritis dan dikaitkan dengan literatur terkini yang relevan (jumlah halaman maksimal 30-40\%). Paparan bagian diskusi berisi pemberian makna secara substansial terhadap hasil analisis dan perbandingan dengan temuan-temuan sebelumnya berdasarkan hasil kajian pustaka yang relevan, mutakhir dan primer. Perbandingan tersebut sebaiknya mengarah pada adanya perbedaan dengan temuan penelitian sebelumnya sehingga berpotensi untuk menyatakan adanya kontribusi bagi perkembangan ilmu.

Berdasarkan penelitian sebelumnya yang dilakukan oleh Pawulan dkk. (2018) terdapat hubungan positif yang signifikan antara kelekatan orang tua dengan regulasi emosi remaja. Semakin tinggi skor kelekatan orang tua makin tinggi pula skor regulasi emosi, begitu pula sebaliknya. Dalam penelitian sebelumnya yang dilakukan oleh Efriani (2019) memiliki hasil adanya hubungan positif antara kelekatan orang tua dan anak dengan regulasi emosi, semakin tinggi kelekatan orang tua dan anak maka 
makin tinggi pula regulasi emosi remaja. Berdasarkan penelitian ini pada alat ukur regulasi emosi mempunyai penilaian skor yang tidak dapat ditotal karena keduanya memiliki konsekuensi yang berbeda, cognitive reappraisal merupakan strategi yang berfokus pada proses awal atau anteseden, sedangkan expressive suppression berfokus pada respon (Gross \& John, 2003).

Salah satu hal yang menghubungkan kelekatan aman dan cognitive reappraisal adalah seberapa erat suatu hubungan. Individu dengan kelekatan aman memerlukan cognitive reappraisal lebih sering dalam hubungan yang memiliki nilai yang tinggi dan yang mereka anggap dekat. Dengan meregulasi emosi menggunakan cognitive reappraisal dalam hubungan yang berharga, individu dengan kelekatan aman akan menunjukkan emosi yang ia rasakan dikarenakan kelekatan dari suatu hubungan tersebut, dimana hal ini akan membantu individu dalam mempertahankan ikatan kelekatan (Winterheld, 2015). Hal ini menunjukkan semakin sering individu menggunakan cognitive reappraisal dalam regulasi emosinya, semakin lekat pula hubungan kelekatannya. Hal ini sejalan dengan hasil penelitian Turliuc \& Bujor (2013) mengungkapkan bahwa apabila pengenalan emosi yang dibangun dari interaksi ibu dan ayah secara positif, anak akan mengembangkan kelekatan aman dan akan memahami alasan ia merasakan emosi-emosi utamanya cara dalam meregulasi emosinya atau cognitive reappraisal. Pada expressive suppression juga termasuk menghambatnya pengalaman emosional itu sendiri, yakni mencoba untuk tidak merasakan emosi tertentu. Expressive suppression dapat mengurangi pengalaman subjektif pada emosi positif tetapi tidak berpengaruh pada pengalaman subjektif dari emosi negatif. Hal ini termasuk upaya dalam mengatur emosi negatif, seperti marah dan cemas. Selain itu, expressive suppression secara konsisten dikaitkan dengan peningkatan sikap simpatik individu (Gross, 2007).

\section{S I M P U L A N}

Berdasarkan hasil analisis yang telah dilakukan, penulis menyimpulkan bahwa terdapat hubungan positif antara parent attachment dengan kemampuan regulasi emosi cognitive reappraisal pada remaja. Serta, hubungan negatif antara parent attachment dengan kemampuan regulasi emosi expressive suppression pada remaja.

Saran bagi orang tua, diharapkan orang tua selalu menemani, memberi perlindungan anak, serta menjadi sandaran bagi anak. Bagi remaja, diharapakan dapat mengutarakan emosinya pada orang tua dan tidak menghambat pengalaman emosinya tersendiri. Bagi peneliti selanjutnya dapat mengembangkan kelekatan teman sebaya dengan regulasi emosi remaja dan mempertimbangkan beberapa faktor lainnya, seperti usia dan jenis kelamin.

\section{U C A P A N T ERIMAKASIH}

Penulis berterima kasih kepada partisipan yang telah meluangkan waktunya dengan sejumlah data informatif guna melengkapi penelitian skripsi ini. Serta kepada pihak-pihak yang tidak dapat disebutkan satu persatu yang telah membantu penulis dalam penyusunan penelitian ini.

\section{DEKLARASI POTENSI TER JADINYA KONFLIK KEPENTINGAN}

Faadhila Syafi Amira dan Endah Mastuti tidak bekerja, menjadi konsultan, memiliki saham, atau menerima dana dari perusahaan atau organisasi manapun yang mungkin akan mengambil untung dari diterbitkannya naskah ini. 


\section{P USTAKA ACUAN}

Alfian, M. (2014). Regulasi Emosi pada Mahasiswa Suku Jawa, Suku Banjar, dan Suku Bima. Jurnal Ilmiah Psikologi Terapan, 02(02), 263-275.

Armsden, G. C., \& Greenberg, M. T. (2009). The inventory of parent and peer attachment: Individual differences and their relationship to psychological well-being in adolescence. https://doi.org/10.1007/BF02202939

Dewi, E. F. (2019). Pengaruh Kelekatan dengan Orangtua Terhadap Efikasi Diri Akademik pada Remaja Awal Skripsi.

Efriani, N. (2019). Hubungan antara kelekatan orang tua-anak dengan regulasi emosi remaja. In Psikologi. http://eprints.ums.ac.id/71571/1/NASKAH PUBLIKASI.pdf

Gross, J. J. (1998). The emerging field of emotion regulation: An integrative review. Review of General Psychology, 2(3), 271-299. https://doi.org/10.1037/1089-2680.2.3.271

Gross, J. J. (2007). Handbook of Emotion Regulation. In The Guilford Press. https://doi.org/10.1088/1751-8113/44/8/085201

Gross, J. J., \& John, O. P. (2003). Individual Differences in Two Emotion Regulation Processes: Implications for Affect, Relationships, and Well-Being. Journal of Personality and Social Psychology, 85(2), 348-362. https://doi.org/10.1037/0022-3514.85.2.348

Nisfiannoor, M., \& Kartika, Y. (2004). Hubungan antara regulasi emosi dan penerimaan kelompok teman sebaya pada remaja. Jurnal Psikologi, 2(2), 160-178.

NusaBali.com. (2019). 9,8 Persen Pemuda di Bali Idap Gangguan Emosional. https://www.nusabali.com/berita/52576/98-persen-pemuda-di-bali-idap-gangguan-emosional

Pawulan, R. A., Loekmono, L., \& Irawan, S. (2018). Hubungan Antara Kelekatan Orangtua Dengan Regulasi Emosi Remaja Pondok Pesantren Agro “Nuur El-Falah" Salatiga. Psikologi Konseling, 13(2), 231-248. https://doi.org/10.24114/konseling.v13i2.12194

Santrock, J. W. (2003). Adolescence perkembangan remaja. Erlangga.

Santrock, J. W. (2012). Life-span development - 13th edition. PT. Gelora Aksara Pratama.

Santrock, J. W. (2014). Adolescence (Fifteenth). McGraw-Hill Education.

Sepda, D. I. (2018). PENGARUH COGNITIVE BEHAVIOR GROUP THERAPY TERHADAP PENINGKATAN REGULASI EMOSI PADA ATLET TIM PERSEGRES GRESIK.

Steinberg, L. (2014). Adolescence (Tenth Edit). McGraw-Hill Education.

Turliuc, M. N., \& Bujor, L. (2013). Emotion Regulation between Determinants and Consequences. Procedia - Social and Behavioral Sciences, 76, 848-852. 
https://doi.org/10.1016/j.sbspro.2013.04.218

Winterheld, H. A. (2015). Calibrating Use of Emotion Regulation Strategies to the Relationship Context: An Attachment Perspective Heike A. Winterheld.pdf. Journal of Personality, 370-380. 